\title{
The competency profile of online BMA graduates viewed from a job market perspective
}

\section{Àngels Fitó Bertran', María Jesús Martínez Argüelles² and Soledad Moya Gutiérrez ${ }^{3}$}

\author{
1. Open University of Catalonia (UOC), Spain | afitob@uoc.edu \\ 2. Open University of Catalonia (UOC), Spain | mmartinezarg@uoc.edu \\ 3. EADA Business School, Spain | smoyag@eada.edu
}

Submitted in: November 2013

Accepted in: February 2014 Published in: May 2014

\section{Recommended citation}

Fitó, À., Martínez, M.J. \& Moya, S. (2014). The competency profile of online BMA graduates viewed from a job market perspective. RUSC. Universities and Knowledge Society Journal, 11(2). pp. 12-25. doi http://dx.doi.org/10.7238/rusc.v11i2.2053

\begin{abstract}
One of the cornerstones of the European Higher Education Area is its emphasis on a higher education that prepares graduates for a profession. Within this context, competencies play a key role in the design of degree courses because they constitute dynamic elements that enable higher education institutions to address the changing needs of society. In this setting, generic competencies become particularly relevant for the job market.

Additionally, in recent years we have seen a significant increase in the number of online higher education options. Although there has been a lot of research into the effectiveness of e-learning, very few studies have actually looked into the employability potential of online graduates.

This study analyses the impact that the online training methodology has on the employability potential of Business Management and Administration (BMA) graduates, and it does so from a two-fold perspective - that of online students and graduates themselves, and that of employers - by appraising the level of acquisition of generic competencies that are essential to the profile of the online BMA graduate. The findings show that online graduates have a positive appraisal of their education, which contrasts with their negative perception of how this training is appraised by the job market. On the other hand, business employers consider that, even though the competency level of online graduates may be lower in some of these competencies (teamwork, leadership) when compared to face-to-face students, it is similar in most of them and even higher in others (using ICT, searching for and managing information and time management, among others). These findings point to a shift in the way employers perceive online graduates and their ability to compete with face-to-face students.
\end{abstract}

\section{Keywords}

European Higher Education Area, generic competencies, employability, e-learning, Business Management and Administration 


\section{El perfil competencial de los graduados de Administración y Dirección de Empresas en línea: una visión desde el mercado de trabajo}

\section{Resumen}

Uno de pilares sobre los que se sustenta la construcción del espacio europeo de educación superior es la apuesta por una formación universitaria profesionalizadora. Las competencias se convierten en el eje fundamental del diseño de las titulaciones, al ser los elementos dinámicos que permiten responder a las necesidades cambiantes de la sociedad. Y las competencias transversales adquieren un papel preponderante dentro del perfil competencial demandado por el mercado de trabajo.

Asimismo, en los últimos años se está produciendo un crecimiento significativo de la oferta de formación superior en línea. Si bien existen múltiples investigaciones que han explorado la efectividad instruccional del e-learning, aún son muy escasos los estudios sobre el potencial de empleabilidad de los graduados en línea.

En esta investigación se analiza el impacto de la metodología formativa, en línea, sobre el potencial de empleabilidad de los graduados de Administración y Dirección de Empresas (ADE). Este análisis se realiza desde la perspectiva de los propios estudiantes y graduados en línea, y los empleadores, a través de la valoración del nivel de adquisición de competencias transversales esenciales para el perfil competencial del graduado de ADE. Los resultados muestran una visión favorable de los graduados en línea respecto a su propia formación, lo que contrasta con su percepción negativa sobre cómo esta formación es valorada en el mercado de trabajo. Sin embargo, los empresarios consideran que aunque el nivel competencial de los graduados en línea es inferior en alguna de las competencias (trabajo en equipo, liderazgo), es similar en la gran mayoría e incluso superior en algunas de ellas (uso de las TIC, búsqueda y gestión de la información, gestión del tiempo, entre otras). Estos resultados confirman el cambio de tendencia de los empleadores en su percepción sobre los graduados en línea y su capacidad de competir con estudiantes presenciales.

\section{Palabras clave}

espacio europeo de educación superior, competencias transversales, empleabilidad, e-learning, administración y dirección de empresas 


\section{Introduction}

In Europe, the Sorbonne 1998 and the Bologna 1999 Declarations laid the foundations for building the European Higher Education Area (EHEA). One of the cornerstones of this reform process is its emphasis on a career-oriented university education that enhances graduates' employability.

The Sorbonne declaration of 25th of May 1998, which was underpinned by these considerations, stressed the Universities' central role in developing European cultural dimensions. It emphasised the creation of the European area of higher education as a key way to promote citizens' mobility and employability and the Continent's overall development. (The EHEA Joint Declaration of European Ministers of Education convened in Bologna on the $19^{\text {th }}$ of June 1999).

Within this context, the EHEA regards competencies as a key element of syllabus design (Tymon, 2013). Competencies have become a dynamic point of reference that gives universities the necessary flexibility for them to address the demands of a changing society (Wagenaar, 2003, 2005). Two types of competencies were identified: specific and generic. The former are specific to a particular professional profile whereas the latter have to do with broad-spectrum capabilities that are not specific to a profession or an organisational environment. Universities have taken on the responsibility of providing their students with comprehensive training for the acquisition of both specific and generic competencies.

Since then, generic competencies have acquired an increasingly important role in that they clearly bring the academic and professional worlds closer together and are fundamental to addressing the constantly changing demands of society. Another significant reason for their rise in popularity is that more and more authors consider these personal qualities as the key to success in selection processes (Branine, 2008; Tymon, 2013).

This emphasis on education for employability is especially relevant in the case of graduates in Business Management and Administration (BMA), not only because BMA is one of the careers at the top of the list of job offers in Spain (for example, 4.2\% of Adecco job offers concern this field according to their 2013 report), but also because it encompasses an essential leadership role for managing the transition towards a knowledge-based society (Bangemann, 1996; Shefrin, 2009; Jackson, 2012; Barajas, 2012).

Various research studies have analysed the competency profile that the job market demands of BMA graduates (Burchell, Hodges, \& Rainsbury, 2001) and the gap between these and the competencies that graduates actually develop at their respective universities (Hodges \& Burchell 2003). Although the findings vary greatly as to the list of different competencies and their relative importance, there seems to be some consensus on the fact that they all emphasise the importance of personal attributes above technical skills (Tymon, 2013; Branine, 2008; Liston, 1998; Meade \& Andrews, 1995; Sweeney \& Twomey, 1997; Stasz, 1997; Weisz 1999).

The Bologna reform began to be implemented in Spain in the late 2000s, when universities began offering new courses adapted to the EHEA. Since then, substantial changes have taken place in the socioeconomic environment. Chief among them has been the crisis, the economic recession that has hit the country hard, causing unemployment rates to soar and forcing many companies to either close or reformulate their strategies. If the design of competency-based university courses is founded on their ability to address the needs of a changing society, then the transformations that have taken place in recent years will probably require adaptations to the competency profile of graduates in general and of BMA graduates in particular. 
Moreover, in recent years we have witnessed a significant rise in the number of online higher education options for both master's degree courses and undergraduate courses, either in hybrid formats (face-to-face and online) or exclusively online. Although several research studies have looked into the effectiveness of e-learning versus faceto-face teaching methodologies (Berg, 2002; Chaney, 2202; Krentler \& Willis-Flurry, 2005), there are very few studies in the literature that focus on the employability potential of online graduates, especially in non-academic sectors. However, given the constant increase in the number of online education options and the decrease in job vacancies, it is precisely within this employment-oriented paradigm of education that we really need to know how the job market actually appraises online graduates.

The study presented below seeks to address these issues and looks into the impact that the training methodologies, face-to-face versus online, have on the perceived quality of training in generic competencies and consequently on the employability potential of graduates of one of the degree courses that is in greatest supply and demand: the BMA degree. We shall perform this analysis both from the perspective of online students and graduates themselves and from that of employers.

We hope the findings will prove useful to academic institutions offering distance education in general and BMA degrees in particular by helping them to find out the level of acceptance that their courses have in the job market and establishing guidelines for them to improve the design, implementation and commercialisation of their courses, with the ultimate aim of training people with high employability potential.

\section{Previous literature}

A large body of literature has explored the expansion process of online education, highlighting its virtues and drawbacks. Some studies have focused on its deficits due to the limitations on interaction between the student and the instructor (Berg, 2002; Potashnik \& Capper, 1998). Others have highlighted its instructional effectiveness for both students (Chaney, 2002) and educators (Edwards et al., 2000) in disciplines such as Business Management (Krentler \& Willis-Flurry, 2005), Education (Bernardo, 2004), Law (Neil, 2004) and even in Healthcare Sciences (Mash et al., 2005), a discipline that tends to be more reticent when it comes to exploring its possibilities. Certain studies have also shown that this teaching format is equally valid for large corporations and small companies (Zager, 2001).

However, few studies have focused their efforts on clarifying how the job market perceives this modality of education. Regarding the stance taken by academia as an employer, the studies we analysed point to a change in the degree of acceptance of online degrees, initially more hesitant and then more favourable. Patrick and Costin (2005) cite a study by Giannoni and Teone (2003) to highlight the fact that, in academia, e-learning is regarded as second best. Adams and DeFleur $(2005,2006)$ corroborated this resistance towards online degrees in their survey on doctoral studies, where they observed that $98 \%$ of a sample of 109 employers preferred to hire candidates with a traditional degree. Furthermore, a later study by Flowers and Baltzer (2006) arrived at similar conclusions, demonstrating that the surveyed sample was less inclined to hire candidates with online doctorates as full-time university lecturers with stable prospects.

In contrast, more recent studies seem to demonstrate a greater degree of acceptance of online degrees. Guendoo (2007, 2008), using the Delphi method, interviewed 52 administrators of the 145 most important community colleges in the United States and found that online courses did not constitute an obstacle for a candidate when it came to getting a job. In this respect, Guendoo went on to say that "One can predict that the gap in perception

RUSC VOL. 11 No 2 Special Issue | Universitat Oberta de Catalunya and University of New England | Barcelona, May 2014

@ Àngels Fitó, María Jesús Martínez and Soledad Moya |@ FUOC, 2014 | The competency profile of online BMA graduates.. 
between subjects of this study (community college leaders) and those of the Adams and DeFleur study [traditional four-years colleges] will continue over time" (Guendoo, 2008, p.4).

In other fields such as industry, the first study - conducted by Chaney (2002) - focused on the perception of online degrees in the pharmaceutical industry and concluded that acceptance of online degrees was on the rise. However, a similar study by Adams, DeFleur and Heald (2007), which surveyed professionals linked to the healthcare sector, found that the majority of employers (95\%) preferred candidates with traditional degrees (irrespective of their professional specialisation). Another study by Adams and DeFleur (2006) concluded that a candidate who had obtained a degree either totally or partially in an online environment did not have the same probabilities of success as another candidate who had graduated in a face-to-face learning environment. In the case of jobs in Accounting, Business Management, Engineering and Information Technologies, 96\% of employers preferred candidates with traditional degrees. Even when presented with the option of hybrid degrees, 75\% preferred the face-to-face option (Adams \& DeFleur, 2006).

In a qualitative survey that looked into employers' perceptions of e-learning, Seibold (2007) interviewed six heads of human resources in large service companies who were likely to select people with a basic profile requiring BMA qualifications. From the findings of her research she concluded that employers perceived that people acquired different competencies in an e-learning environment (self-motivation and information and communication technologies [ICT]) than in a traditional face-to-face learning environment (communication and group work competencies). From this perspective, they tended to prefer hybrid education formats. Furthermore, she highlighted the fact that one of the factors accounting for this positive perception of e-learning was the employers' own experience of distance learning environments. Consequently, she drew the conclusion that online education was beginning to affect personnel selection processes: "If asked five years ago, four participants said they would have had a negative perception. If asked again in five years, what will their answers be?" (Seibold, 2007, p. 107).

Finally, and by way of conclusion, it should be pointed out that, according to the literature, the format of one's education has an impact on access to the job market and career progression wherein online qualifications are still stigmatised precisely because of the concerns that people have about the development of certain competencies through this learning format (Wagner, Hassanein, \& Head, 2008). However, given its advantages in terms of costs and opportunity, online university education will continue to expand and turn out more and more degree holders for the job market. This is bound to affect selection processes, where acceptance of online qualifications is expected to rise. The purpose of the study presented below is to find out the current degree of acceptance of online BMA graduates, with an emphasis on the acquisition of generic competencies, an increasingly crucial factor in selection processes.

\section{Methodology}

The first step in this research survey was to draw up a questionnaire, which, irrespective of the type of training (faceto-face or online), featured the core generic competencies in the competency profile of a BMA graduate and could be used to interview students, graduates and employers. The generic competencies included in the questionnaire were selected from those featured in the Tuning Project and in the Libro Blanco del Grado en Economía y Empresa (ANECA, 2005). Neither of these previous references drew a distinction between online and face-to-face education. We then carried out in-depth interviews with four general managers of companies that undertook personnel selection in the area of BMA. This enabled us to get their opinions as to whether the questionnaire adequately covered the competencies that the job market values today, almost a decade after the reference documents

RUSC VOL. 11 No 2 Special Issue | Universitat Oberta de Catalunya and University of New England | Barcelona, May 2014

@ Àngels Fitó, María Jesús Martínez and Soledad Moya |@ FUOC, 2014 | The competency profile of online BMA graduates.. 
were first published. Their comments and suggestions enabled us to update, complete and make changes to the initial competencies list and come up with a definitive list of 20 generic competencies. This questionnaire was then administered online. The respondents were first-year students and graduates of the BMA degree at the Open University of Catalonia (UOC), Spain (a university that only offers fully online courses), and business managers associated with Fundación Factor Humano (a foundation that unites professionals in the field of Human Resources Management who are interested in creating value in this field and contributing to a society where more caring organisations predominate) and with the Catalan Association of Accounting and Management (ACCID). We chose ACCID because its mission explicitly states that it intends to be a nexus for professionals and academics who work in Catalonia in the field of Business Management. This association is formed by business managers from all areas of the Catalan corporate world, and companies of all sizes and sectors are represented. This field work was carried out between April and June 2013. We received properly completed surveys from 299 first-year BMA students and 40 BMA graduates. We also engaged the participation of 242 business managers (23 from Fundación Factor Humano and the rest from ACCID). All the questionnaires sent out contained descriptive variables, thus enabling future research studies to analyse the determinants of the responses. These variables were especially relevant in the case of business managers because their training would almost certainly have been undertaken in different learning formats (face-to-face and online), whereas the students and graduates only came from an e-learning background.

\section{Analysis and results}

Firstly, it should be noted that although we surveyed first-year students and graduates, we did not find any significant differences between the responses of these two groups to the questionnaire we administered. Thus, for example, all of them considered that, given the present-day crisis, the employability potential and/or prospects for promotion of BMA graduates were reasonable. They assigned an average score of 3.34 points (on a scale from 1 to 5).

Graph 1. Quality of online BMA education (frequencies)

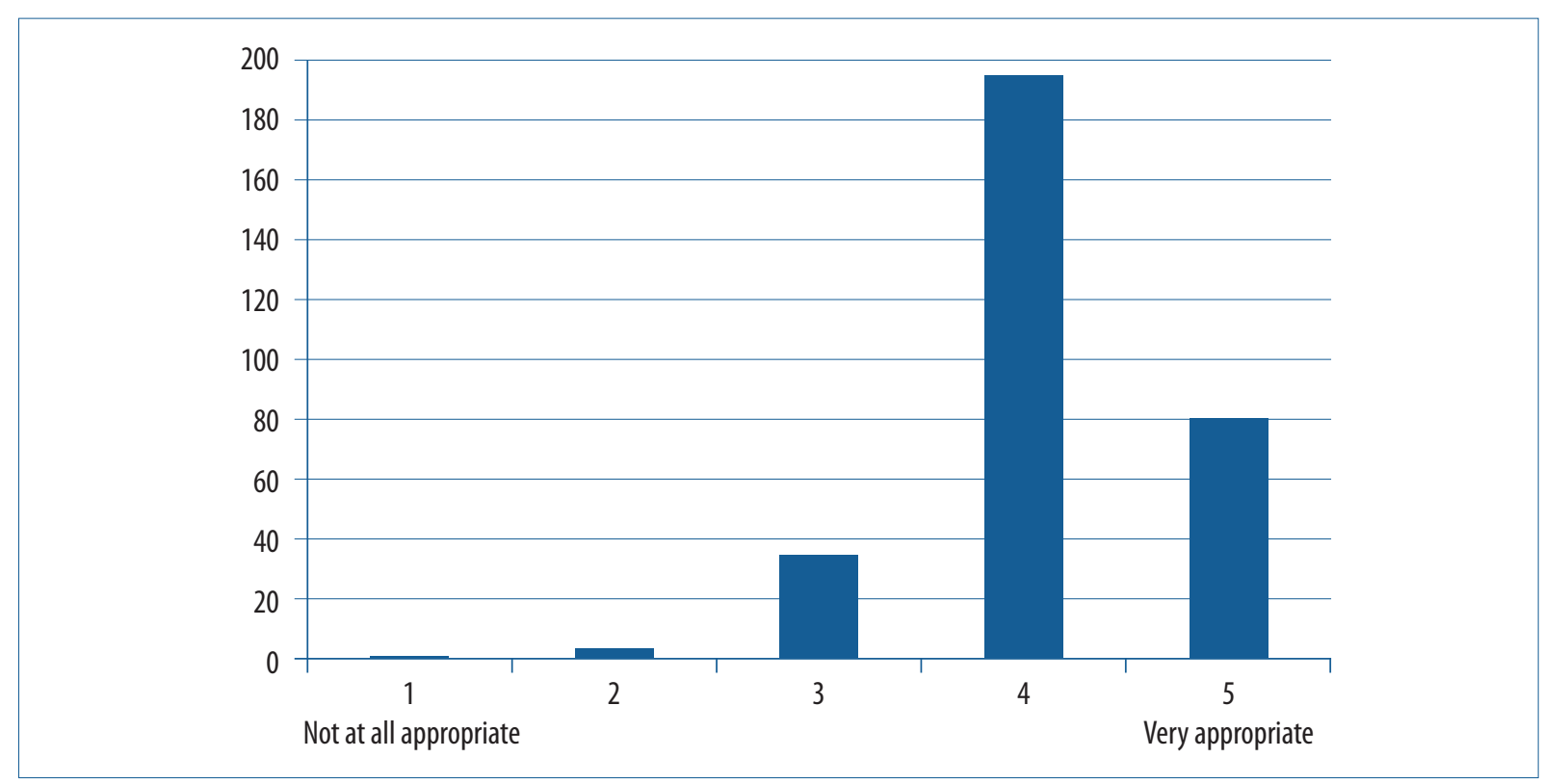


These students and graduates seemed to feel satisfied with the education they had received or were receiving. They gave an average score of 4.12 when they were asked to rate the quality of this e-learning.

Furthermore, when asked how they perceived the quality of the training they had received in relation to what they could have received in a face-to-face university, almost 40\% thought that there were no significant differences between one form of education and the other. Some 15\% considered that their training was worse than what they could have received in a face-to-face setting and the rest considered that it was better (37\%) or much better (9\%).

This positive view of their own online education contrasts with the negative view that they perceived the job market had of their degree obtained via this form of education. In fact, when they were asked how they thought their degree might be viewed in the job market, almost 40\% (36.6\% worse; 2.4\% much worse) considered that it would be regarded as being of worse quality than if it had been obtained in a face-to-face education setting, whereas only $20 \%$ thought that it would be viewed in a better light.

Graph 2. Students' perceptions of the quality of their online education: their own versus those of employers

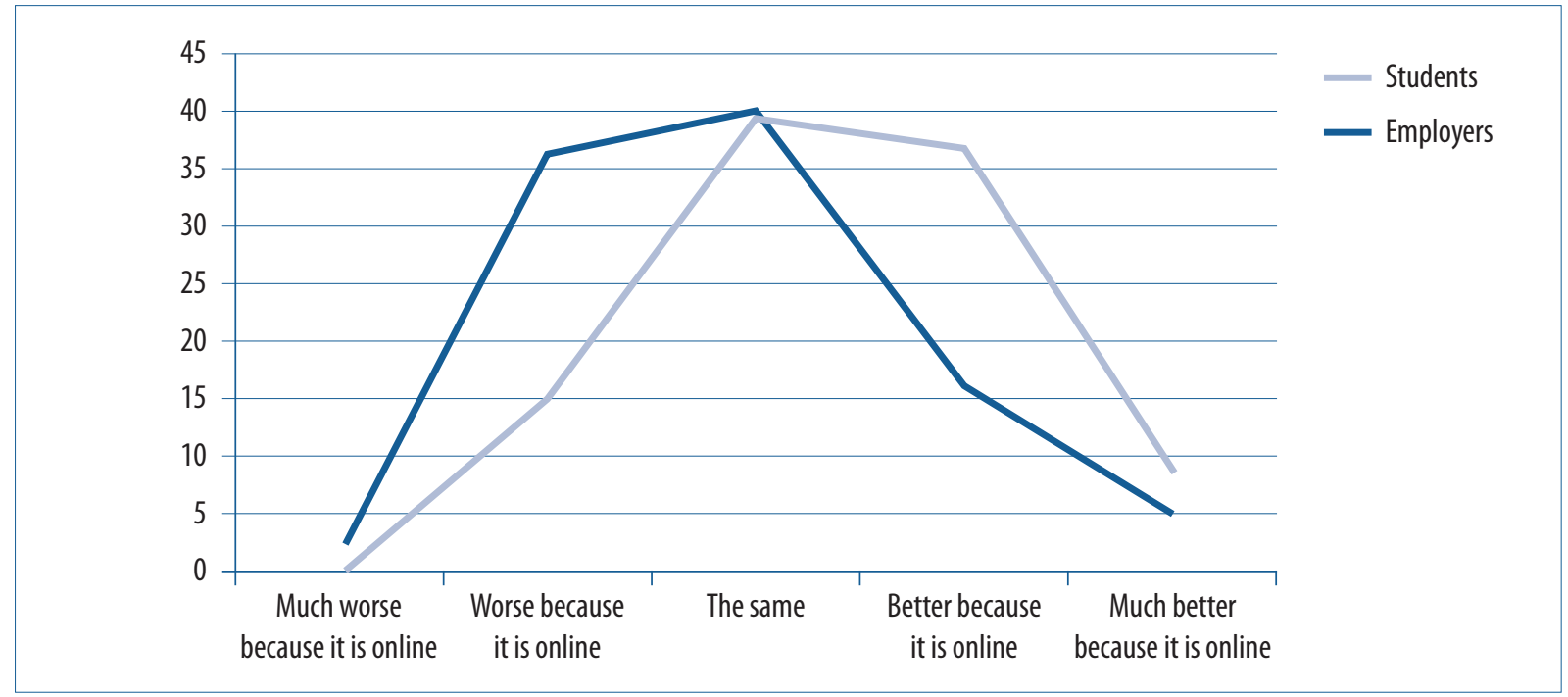

This perception by the students and graduates could be considered especially relevant if we take into account that the large majority of these students had prior experience in the job market (96.2\%) and of face-to-face university education (because approximately $80 \%$ of them had begun their university studies in a face-to-face format).

We then went on to contrast the students' views of the effectiveness of online education in transmitting generic competencies with the business managers' views. The potential employers of BMA graduates were asked to what extent they considered that each of the 20 generic competencies listed in the questionnaire had been acquired by an online graduate, compared with a face-to-face graduate. As shown in Table 1 below, the responses varied depending on the competency considered in each case. We found that the responses were diverse for each competency; some employers thought that graduates reached a better competency level thanks to the online methodology, some thought it was the same or equivalent, and others thought it was worse.

We can however distinguish three clearly differentiated trends: 
Table 1. Employers' perceptions of competency acquisition in online versus offline settings

\begin{tabular}{|c|c|c|c|c|c|}
\hline \multirow[b]{2}{*}{ Competencies } & \multicolumn{3}{|c|}{ Degree of acquisition (\%) } & \multicolumn{2}{|c|}{ Importance } \\
\hline & $\begin{array}{l}\text { Worse } \\
\text { online }\end{array}$ & Equivalent & $\begin{array}{l}\text { Better } \\
\text { online }\end{array}$ & Average & Dev. \\
\hline Behaving in an ethical and socially responsible fashion & 5.7 & 92 & 2.4 & 4.46 & 0.82 \\
\hline Learning and unlearning & 7.7 & 82.3 & 10 & 4.19 & 0.90 \\
\hline Decision making & 11 & 78.5 & 10.5 & 4.20 & 0.82 \\
\hline Analysis and synthesis & 8.5 & 74.5 & 17 & 4.35 & 0.79 \\
\hline Results oriented & 9.2 & 74.4 & 16.4 & 4.05 & 0.82 \\
\hline Criticism and self-criticism & 18.9 & 74.1 & 7.1 & 4.09 & 0.81 \\
\hline Working in an international setting & 11 & 72.4 & 16.7 & 3.88 & 0.96 \\
\hline Problem solving & 15.8 & 70.8 & 13.4 & 4.45 & 0.74 \\
\hline Using and applying ICT & 5.7 & 26.7 & 67.6 & 4.23 & 0.77 \\
\hline Searching for and managing information & 3.8 & 41.8 & 54.5 & 4.15 & 0.83 \\
\hline Time management & 8 & 39.6 & 52.4 & 4.42 & 0.81 \\
\hline Organising and planning work & 7.6 & 42.2 & 50.2 & 4.52 & 0.78 \\
\hline Adapting to change & 7.6 & 66.7 & 25.7 & 4.36 & 0.78 \\
\hline Being creative and innovative (entrepreneurship) & 12.2 & 66.7 & 21.1 & 3.97 & 0.87 \\
\hline Teamwork & 59.6 & 33.8 & 6.6 & 4.52 & 0.87 \\
\hline Leadership & 34.4 & 60.4 & 5.2 & 3.84 & 0.93 \\
\hline Communicating and working with experts in other areas & 31.9 & 55.2 & 12.9 & 4.38 & 0.78 \\
\hline Oral and written communication in a foreign language & 26.4 & 62.7 & 10.8 & 3.90 & 0.86 \\
\hline Oral and written communication in their own language & 25.7 & 61.4 & 12.9 & 4.16 & 0.90 \\
\hline Putting knowledge into practice & 22.9 & 69.5 & 7.6 & 4.24 & 0.76 \\
\hline
\end{tabular}

(1) There is a group of competencies in which the majority of employers (over $70 \%$ of those surveyed) considered that graduates could achieve the same competency level irrespective of the training methodology. Among these competencies are those related to the ability to develop ethical and socially responsible behaviour, to learn and unlearn and to take decisions.

(2) The business managers considered that those students who had obtained their BMA degree in an online setting had acquired a higher level of competency than those who had studied in an offline setting. This was so for competencies such as using and applying ICT, searching for and managing information, time management, and organising and planning work.

(3) Finally, the business managers considered that, for certain competencies it was difficult to reach the same competency level in an online setting as one would reach in an offline setting. The competency which they clearly thought was acquired to a lesser degree in an online setting was that of teamwork. Similarly, a substantial 
percentage of potential employers considered that online graduates were relatively less trained in competencies such as leadership and the ability to communicate and work with experts in other areas.

Hence, from the point of view of our survey respondents, the pejorative view of online education was in no way generalised and must be interpreted in the light of many nuances. When it came to selecting a BMA graduate for a job, the potential employers gave the highest priority (on average) to the ability to organise and plan work as well as the ability to work in a team. These two competencies were already among the five most highly valued competencies in the Tuning project (Gonzalez \&Wagenaar, 2003, 2005). Furthermore, Tymon (2013) has highlighted them as highly valued in a table that sums up other classifications of competencies acquired in previous studies. For these two competencies, the opinions of the majority are totally counterposed as regards the appropriateness of one training methodology or the other. In the case of the ability to organise and plan work, 50.5\% of the respondents considered that e-learning graduates had developed this competency more in-depth than offline learning graduates. In the case of teamwork however, almost $60 \%$ of the employers thought that this competency was much less present or developed in online degrees.

Regarding the rest of the competencies that employers considered most important (the ability to behave in an ethical and socially responsible fashion, and problem solving), we can see that the majority of employers thought that they could be acquired in an equivalent way using either methodology. Another competency that they considered essential was the ability to manage time; the majority thought that it was better acquired in an online setting (52.4\%) or as well as it would be in an offline setting (39.6\%). Only a very small percentage (8\%) thought that it was not acquired as well in an online setting. This perception may have to do with the fact that the students who traditionally opt to take an e-learning education course are people who need to reconcile their professional and personal responsibilities with their studies. Hence, those who finally graduate will have proven that they were able to manage their time effectively in order to achieve several lifetime goals simultaneously.

These perceptions are to a large extent corroborated by the graduates themselves. As shown in Graph 3, the students considered that they were especially well trained in the same competencies as those highlighted by the employers (searching for and managing information, using ICT, organising and planning work) and not as well qualified in aspects related to the ability to work in an international setting, communicating in a foreign language and working in a team. However, it should be pointed out that these perceptions are slightly biased by the fact that when they began taking the degree, it was in the implementation phase and this limited their number of optional subjects. For example, they were not able to take subjects such as International Management.

\section{Conclusions}

Within the context of career-oriented university education and given the increasing number of online education options, this research study has focused on the extent to which obtaining an online degree affects a graduate's employability potential in the field of BMA. It was important to analyse the specific group of BMA graduates for two reasons: firstly because they receive the largest amount of job offers, and secondly because they are expected to take on the role of transforming the traditional company organisation models, which are currently in crisis.

After reviewing the literature, we found that online education was frequently regarded as second best (Patrick \& Costin, 2005), a view that a substantial percentage of online students and graduates in this study shared. Although

RUSC VOL. 11 No 2 Special Issue | Universitat Oberta de Catalunya and University of New England | Barcelona, May 2014

@ Àngels Fitó, María Jesús Martínez and Soledad Moya |@ FUOC, 2014 | The competency profile of online BMA graduates.. 
Graph 3. BMA graduates' self-evaluation of their acquired competency levels (on a scale from 1 to 5)

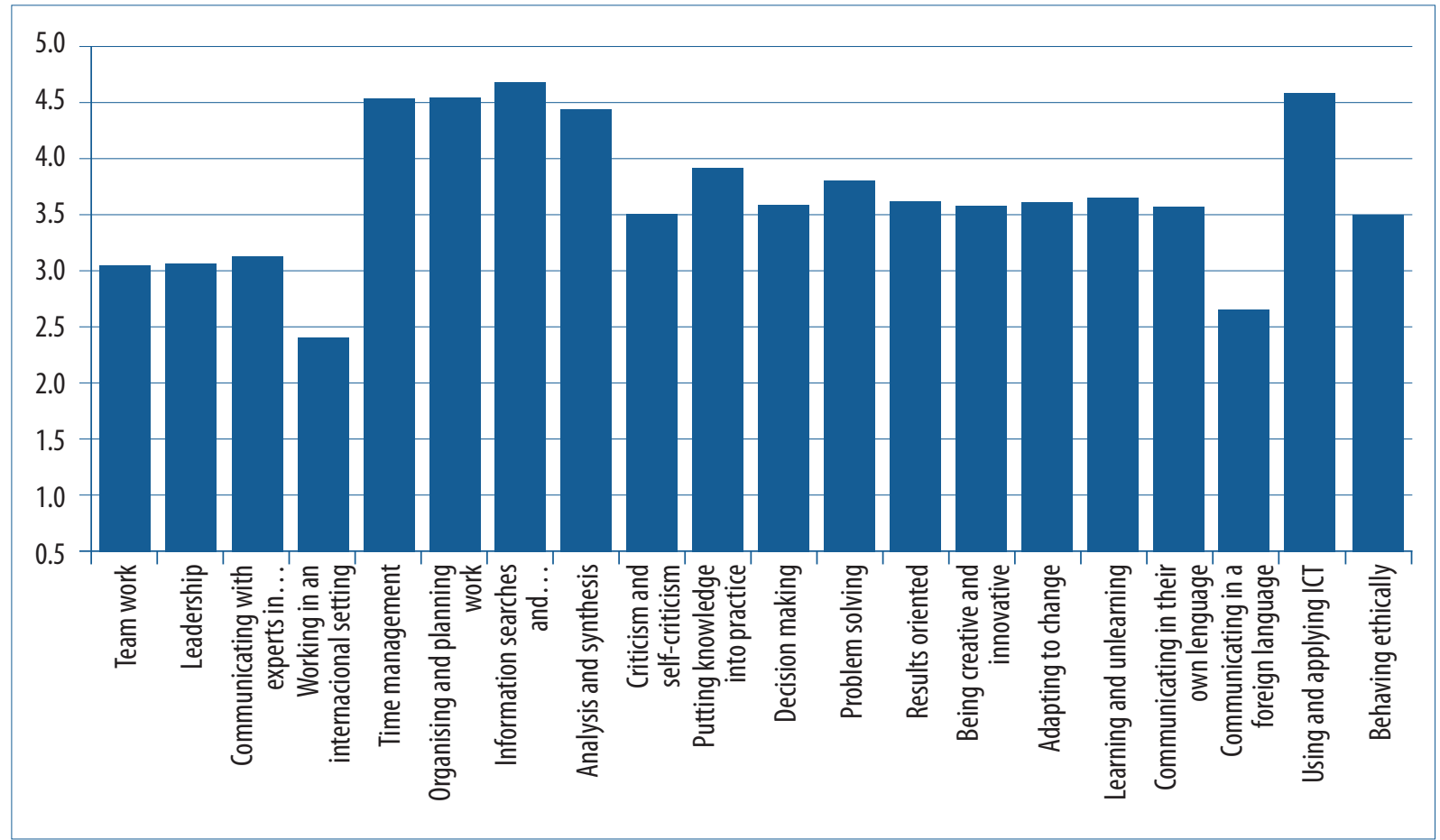

the majority of these online students did not consider that the quality of their education was lower than that of a face-to-face university course (over 45\% actually thought that it was better), approximately $40 \%$ thought that the job market undervalued their degrees because of the fact that it had been taken online.

However, the opinions expressed by the surveyed employers did not allow us to confirm this pejorative view of online education. In fact their opinions were more in line with the findings of Seibold's study (2007). They considered that a large number of generic competencies were acquired just as well in either of the two learning settings. They nevertheless noted differences between the former and the latter graduates; in their opinion online graduates displayed a higher level of competency in certain relevant areas (for example, in organising and planning work) and a lower level in others (above all in teamwork). Moreover, this view was partially corroborated by the graduates' own perceptions of the competency levels that they had achieved in each of these generic competencies.

Adapting to the EHEA and the need to train their students in core generic competencies in order to improve their employability is posing a challenge to all universities alike, both offline and online. The growing number of online higher education options together with an increasingly positive view of this form of training constitutes an opportunity for institutions providing e-learning, of which they should take advantage. They need to contribute to the corroboration and promotion of this positive view by offering higher quality education options that are better suited to the competency profile demanded by the job market. Unlike Seibold (2007), we do not consider it necessary to resort to hybrid models in order to achieve this objective because all the competencies we included in our survey can be developed in an online setting. Through constant efforts to innovate in educational methodology, it is possible to optimally attain all the above-mentioned generic competencies. To this end, it is essential to work on the design of learning systems, processes and activities that facilitate the online acquisition of those competencies in which e-graduates have a lower competency level, especially those that are most highly valued in the job market.

RUSC VOL. 11 No 2 Special Issue | Universitat Oberta de Catalunya and University of New England | Barcelona, May 2014

@i) Àngels Fitó, María Jesús Martínez and Soledad Moya | @ FUOC, 2014 | The competency profile of online BMA graduates. 


\section{References}

Adams, J., \& DeFleur, M. (2005). The acceptability of a doctoral degree earned online as a credential for obtaining a faculty position. The American Journal of Distance Education, 19(2), 71-85. doi http://dx.doi.org/10.1207/ s15389286ajde1902_2

Adams, J., \& DeFleur, M. (2006). The acceptability of online degrees earned as a credential for obtaining employment. Communication Education, 55(1), 32-45. doi http://dx.doi.org/10.1080/03634520500343376

Adams, J., DeFleur, M., \& Heald, G. (2007). The acceptability of a doctoral degree earned online as a credential for health professionals. Communication Education, 56(3), 292-307. doi http://dx.doi.org/10.1080/0363452 0701344959

Allen, E., \& Seaman, J. (2011). Going the Distance Online Education in the United States. Retrieved from http://www. onlinelearningsurvey.com/reports/goingthedistance.pdf

Bangemann, M. (1996). The European Vision of the Information. 10th World Congress Technology and Services in the Information Society, Bilbao, 3rd of June '96. Retrieved from http://europa.eu.int/en/comm/dgiii/speeches/bangwit. htm

Barajas, M. (2002) Restructuring Higher Education institutions in Europe: The case of virtual learning environments. Interactive Educational Multimedia, 5, 1-28. Retrieved from http://www.ub.es/multimedia/iem

Berg, G. A. (2002). Why distance learning? Higher education administrative practices. Westport, CT: Praeger Publishers. doi http://dx.doi.org/10.1016/j.ijmedinf.2004.06.002

Bernardo, V., Ramos, M. P., Plapler, H., Francisco, L., De Figueiredo, P., Nader, H. B., et al. (2004). Web-based learning in undergraduate medical education: development and assessment of an online course on experimental surgery. International Journal of Medical Informatics, 73, 731-42.

Branine, M. (2008). Graduate recruitment and selection in the UK. Career Development International, 13(6), 497-513. doi http://dx.doi.org/10.1108/13620430810901660

Burchell, N., Hodges, D., \& Rainsbury, E. (2001). What competencies do business graduates require? Perspectives of New Zealand stakeholders. Journal of Cooperative Education, 35(2-3), 11-20.

Chaney, E. G. (2002). Pharmaceutical employers' perceptions of employees or applicants with e-degrees or online coursework. (Doctoral dissertation). Indiana State University, Indiana, USA. Available from ProQuest Digital Dissertations database. (Publication No. AAT 3061561).

Columbaro, N., \& Monaghan, C. (2009) Employer perceptions of online degrees: a literature review. Online Journal of Distance Learning Administration, 12(1).

Edwards, M. E., Cordray, S., \& Dorbolo, J. (2000). Unintended benefits of distance-education technology for traditional classroom teaching. Teaching Sociology, 28, 386-391. doi http://dx.doi.org/10.2307/1318588

Eurostats (2013). Retrieved from http://epp.eurostat.ec.europa.eu/statistics_explained/index.php/Employment_ statistics

Flowers, J., \& Baltzer, H. (2006). Hiring Technical Education faculty: Vacancies, criteria, and attitudes toward online doctoral degrees. Journal of Industrial Teacher Education, 43(3).

González, J., \&Wagenaar, R. (2003). Tuning educational structures in Europe. Final report. Pilot Project-Phase 1 (ANECA, 2003).

González, J., \& Wagenaar, R. (2003). Tuning educational structures in Europe. Informe final. Proyecto Piloto-Fase 1 (ANECA (2005). Tuning educational structures in Europe. Final report. Pilot Project-Phase 2 (ANECA, 2005).

RUSC VOL. 11 No 2 Special Issue | Universitat Oberta de Catalunya and University of New England | Barcelona, May 2014 @i) Àngels Fitó, María Jesús Martínez and Soledad Moya | @ FUOC, 2014 | The competency profile of online BMA graduates. 
Guendoo, L. (2007). Credibility challenges to online doctoral graduates seeking faculty positions: A community college perspective. (Doctoral dissertation). Capella University, Minnesota, USA. Available from Dissertations \& Theses: A\&l database. (Publication No. AAT 3284074).

Guendoo, L. (2008). Community colleges friendlier to online PhDs. Online Journal of Distance Learning Administration, 11(3). Retrieved from http://www.westga.edu/ distance/ojdla/fall113/guendoo113.html

Hodges, D., \& Burchell, N. (2003). Business graduate competencies: Employers'views on importance and performance. Asia-Pacific Journal of Cooperative Education, 4(2), 16-22.

Jackson, D. (2012). Non-technical competencies in undergraduate business degree programs: Australian and UK perspectives. Studies in Higher Education, 37, 5. doi http://dx.doi.org/10.1080/03075079.2010.527935

Krentler, K. A., \& Willis-Flurry, L. A. (2005). Does Technology Enhance Actual Student Learning? The Case of Online Discussion Boards. Journal of Education for Business, July/August, 316-321. doi http://dx.doi.org/10.3200/ JOEB.80.6.316-321

Liston, C. B. (1998). Graduate attributes survey (GAS): Results of a pilot study. Journal of Institutional Research, 7(1), 57-73.

Mash, R. J., Marais, D., Van Der Walt, S., Van Deventer, I., Steyn, M., \& Labadarios, D. (2005). Assessment of the quality of interaction in distance learning programmes utilising the internet (WebCT) or interactive television (ITV). Medical Education, 39, 1093-1100. doi http://dx.doi.org/10.1111/j.1365-2929.2005.02315.x

Meade, P., \& Andrews, R. (1995). Measuring employer satisfaction in higher education. The Quality Magazine, April, 52-53.

Neil, M. (2004). High marks. ABA Journal, 90, 14.

Potashnik, M.., \& Capper, J. (1998). Distance education: Growth and diversity. Finance and development, 35, 42-45.

Seibold, K. N. (2007). Employers' perceptions of online education. (Doctoral dissertation). Oklahoma State University, Oklahoma, USA. Available from ProQuest Digital Dissertations database. (Publication No. AAT 3274545).

Shefrin, H. (2009), Ending the management illusion: preventing another financial crisis. Ivey Business Journal, January/ February. Retrieved from http://www.iveybusinessjournal.com/article.asp?intArticle_ID=805

Stasz, C. (1997). Do employers need the skills they want? Evidence from technical work. Journal of Education and Work, 10(3), 205-223. doi http://dx.doi.org/10.1080/1363908970100301

Sweeney, M., \& Twomey, P. (1997, August). Preparing graduates for 2020: The role of cooperative education. Paper presented at the 10th World Conference on Cooperative Education. Cape Town, South Africa.

Tymon, A. (2013). The student perspective on employability. Studies in higher education, 38(6), 841-856. doi http:// dx.doi.org/10.1080/03075079.2011.604408

Weisz, M. (1999). The added value of undertaking cooperative education year: The measurement of student attributes. Melbourne, Australia: Royal Melbourne Institute of Technology.

Yick, A., Patrick, P., \& Costin, A. (2005). Navigating distance and traditional higher education: Online faculty experiences. The International Review of Research in Open and Distance Learning, 6(2). Retrieved from http://www. irrodl.org/index.php/irrodl/article/view/235/853

Zager, M. (2001) Online training: A practical alternative for small businesses. Rural Telecommunications, $20,42$. 


\section{About the Authors}

\section{Àngels Fitó Bertran}

afitob@uoc.edu

Lecturer and director of the Economics and Business Studies Department at the Open University of Catalonia, Spain

Àngels Fitó has been the director of the Economics and Business Studies Department at the Open University of Catalonia (UOC), Spain, since 2010. Previously, she combined her teaching activity in other Spanish universities with economic and financial consultancy work. Her research focuses on economic and financial information and on e-learning. She has published her research results in international indexed journals and presented them at international conferences on accounting and financial matters and on education.

Universitat Oberta de Catalunya (UOC)

Estudios de Economía y Empresa

Avenida del Tibidabo, 39-43

08035 Barcelona

Spain

María Jesús Martínez Argüelles

mmartinezarg@uoc.edu

Lecturer, Faculty of Economics and Business, Open University of Catalonia (UOC), Spain

María Jesús Martínez-Argüelles is a lecturer in the field of Business Organisation in the Faculty of Economics and Business at the Open University of Catalonia (UOC), Spain. She is currently the programme director of the bachelor's degree in Business Management and Administration. In the field of research, she is particularly interested in issues relating to the effects of the use of information and communication technologies (ICT) on business strategy and organisation. In this context, she has participated in several research projects and has published articles and presented papers on the effects of ICT in higher education, especially from the perspective of e-learning management. Moreover, she has analysed the use of teleworking and its organisational and work-life balance implications.

Universitat Oberta de Catalunya (UOC)

Estudios de Economía y Empresa

Avenida del Tibidabo, 39-43

08035 Barcelona

Spain 


\section{Soledad Moya Gutiérrez}

smoyag@eada.edu

EADA Business School

Associate Lecturer, Finance and Management Control Department, EADA Business School, Spain

Soledad Moya obtained her bachelor's degree in Business from the University of Barcelona (UB), Spain, and her doctorate (PhD) from Pompeu Fabra University (UPF), Spain. She has held visiting positions at the Autonomous University of Barcelona (UAB), Spain, and at Leeds University Business School, United Kingdom. She has authored many academic and professional articles on the accounting harmonisation process, international accounting and international accounting standards (IFRS), the analysis of financial statements, the economic consequences of accounting standards and the consolidation of financial statements. She has participated in competitive research projects and is currently a member of the research group Gestion y Evaluación de las Organizaciones. She is also a member of the editorial board of Accounting in Europe, Accounting Education: An international journal and the Revista de Contabilidad y Dirección (ACCID).

EADA Business School

Calle de Aragó, 204

o8011 Barcelona

Spain

Original title El perfil competencial de los graduados de Administración y Dirección de Empresas en línea: una visión desde el mercado de trabajo

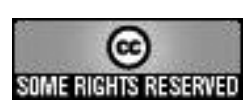

The texts published in this journal are - unless indicated otherwise - covered by the Creative Commons Spain Attribution 3.0 licence. You may copy, distribute, transmit and adapt the work, provided you attribute it (authorship, journal name, publisher) in the manner specified by the author(s) or licensor(s). The full text of the licence can be consulted here: <http://creativecommons.org/licenses/by/3.0/es/deed.en>

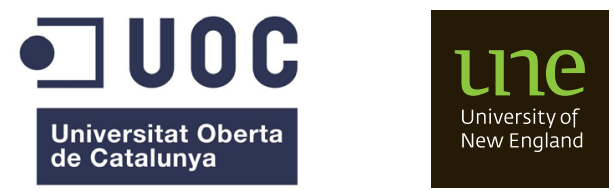

RUSC VOL. 11 No 2 Special Issue | Universitat Oberta de Catalunya and University of New England | Barcelona, May 2014

@a) Àngels Fitó, María Jesús Martínez and Soledad Moya | @ FUOC, 2014 | The competency profile of online BMA graduates.. 